\title{
Keloid of Ears: Recurrence and Its Complications
}

\author{
José Humberto Cardoso Resende*, Ana Paula Rodrigues de Souza, \\ Ellen Karoliny de Souza Arruda, Guilherme Portilho Soares, \\ Gumercindo João de Morais Silva, Gustavo Ferreira Rocha, Pedro Martins Milani, \\ Thiago Calandria Obeid, Tiesca Cândida de Melo, Emídio Silva Falcão Brasileiro
}

UNIFAN, Aparecida de Goiânia, Brasil

Email: *jresen99@hotmail.com

How to cite this paper: Resende, J.H.C., Rodrigues de Souza, A.P., Karoliny de Souza Arruda, E., Soares, G.P., João de Morais Silva, G., Rocha, G.F., Milani, P.M., Obeid, T.C., Cândida de Melo, T. and Brasileiro, E.S.F. (2021) Keloid of Ears: Recurrence and Its Complications. Modern Plastic Surgery, 11, 6-13.

https://doi.org/10.4236/mps.2021.111002

Received: November 10, 2020

Accepted: December 22, 2020

Published: December 25, 2020

Copyright $\odot 2021$ by author(s) and Scientific Research Publishing Inc. This work is licensed under the Creative Commons Attribution International License (CC BY 4.0).

http://creativecommons.org/licenses/by/4.0/

\section{(c) (i) Open Access}

\begin{abstract}
In this case report, we present a male patient who arrived at the hospital for the first time at the age of 8 with giant keloids in both ears and diagnosed by the Dermatology and Plastic Surgery as having the "Disease of Jorge Lobo", which is a fungal infection due to the story of the endemic characteristics. After the first surgical intervention, he received guidance from the team for keloids and left the hospital using elastic mesh and a request to change the place where he lived to reduce his contact with the fungi. Fourteen years later, the patient returned to the Plastic Surgery Service having even larger keloids in both ears, twice the size than the first time. We did the second surgical intervention to remove it, but with the patient's commitment that he would correctly comply with the guidelines determined by the surgical team. After finishing all the steps and a post-operative for the case, we observed the satisfaction and the increase of the patient's mood, happier and without the embarrassment of that physical defect.
\end{abstract}

\section{Keywords}

Keloid, Fibrosis, Disease, Syndrome, Scar, Relapse

\section{Introduction}

The pathophysiology of keloids shows an immunological reaction against sebaceous secretion in patients affected by the disorder, in the occurrence of these lesions. T lymphocytes are attracted to the site with sebaceous secretion, leading to increased collagen formation and greater proliferation of fibroblasts [1].

The reticular dermis is the basic site of keloid changes. In this place, the colla*Work performed in partnership with Universidade Alfredo Nasser (UNIFAN) with Clínica Brasil. 
gen fibers are formed with nodules that increase in size and are distributed irregularly. The skin of a keloid lesion has a flattened epidermis, without hair, sebaceous and sweat glands [2].

Keloids are disorders of skin repair characterized by excessive accumulation of extracellular matrix produced by fibroblasts and occur when there is not a normal healing process. Studies have shown the increased expression of COXs in keloids, suggesting that the pharmacological block could be used in the treatment [3].

Keloids are a pseudotumor proliferation that extends beyond the edges of the initial wound. It is a smaller keloid, a slightly raised and itchy scar that extends over normal tissue. It is an important keloid, a large, elevated, painful scar that protrudes from normal tissue, developed on extensive surfaces, creating pending tumors [4].

Diagnosed by the patient, it does not require laboratory or imaging exams, and, in a biopsy, we usually observe an increase in collagen and elastic fibers [5]. It is mistaken for hypertrophic scarring due to its similarity in pathology. In this paper, we will report the case of an 8-year-old child [6], male, who had rough, hard, with pruritus, gigantic protruding tumors in both ears, and with an onset report after a sting of an unknown insect. He lived in an endemic area, pond type, humid, and contaminated by waste and with the presence of street animals. This type of keloid is described as the disease of Jorge Lobo [7], as a deep, chronic, granulomatous fungal infection originating from trauma and fungal implantation (paracoccidioides loboi et loboa loboi) in cutaneous and subcutaneous tissues with a keloid aspect (Figure 1). It is also called Lacazione, a disease that could infect humans and animals, such as mycoses. First, we programmed to do Beta-therapy [8], use of compressive meshes, and monthly steroid infiltration (triamcinolone). Three months later (Figure 2), we performed the surgical removal of the giant tumors in the ears, with the hope that if the patient did all the recommendations, the lesion would not recur. In addition to all social problems, the patient was bulling in the city where he lived (Figure 3) [9]. We got free beta-therapy, knitwear, and had follow-up for 30 days until discharge (Figure 4).

Years later, at the age of 22, the same patient returned to the Plastic Surgery Service of the HFSE in Rio de Janeiro, with his head covered by the T-shirt, covering the recurrent keloid in both ears. In this second intervention, we removed almost $1 \mathrm{~kg}$ of the operative piece (Figure 5) [10]. The postoperative period was considered satisfactory and more energetic measures for the late postoperative period were passed on to the patient's sister, who promised the team to supervise closely and follow the medical guidelines.

All of our operated patients signed the informed consent form from the hospital and the medical team.

\section{Case Report}

Fourteen years after the first discharge, the patient returns to the hospital with a larger tumor and in the same places. During the physical examination, we found that the keloid of the right ear was smaller than in the left ear. During the second 
removal procedure, we removed $350 \mathrm{mg}$ from the right ear and $650 \mathrm{mg}$ from the left ear, the main piece was $36 \mathrm{~cm}$ long in the shape of a giant "earring" on the left ear (Figure 6) [11]. To perform the surgical removal, we identified piece by piece of keloid, being very careful to leave the skin on both sides, for the end-to-end raffia with simple stitches, separated and using nylon 4.0. We respect the main anatomical accidents that a normal ear has to make it look as good as possible: Helix, shell, lobe, and tragus (Figure 7) [12]. Given the complexity of the surgery, we considered a few scars at the end of the reconstruction. The larger keloids were found on the edges of the helices of both ears (Figure 8) and the pieces were sent to the Pathology Service, which confirmed the "keloid for an undetermined cause" [13].

In the immediate postoperative period, on the day of surgery, we performed a Beta-therapy session with 700 rds, repeated for 7 days interspersed in each ear [14]. On the fifteenth day, we modeled the lead sheet, which was used for 7 days. On the thirtieth day (Figure 9), before discharge, we made an intradermal infiltration with triamcinolone $10 \mathrm{mg}$ [15], and 1/10,000 saline solution on the edges of both ears. The team followed up the patient for six months, once a month, using elastic semi-compressive mesh and without signs of recurrence [16]. We lost contact with the patient one year after the second surgery due to the change in the city. Five years later, we received a call from the patient and we were happy to know that he was married, with a son, employed, and was not ashamed of the small scars left by the last surgical intervention, which is why we decided to make this publication.

$1^{\text {st }}$ extirpation:

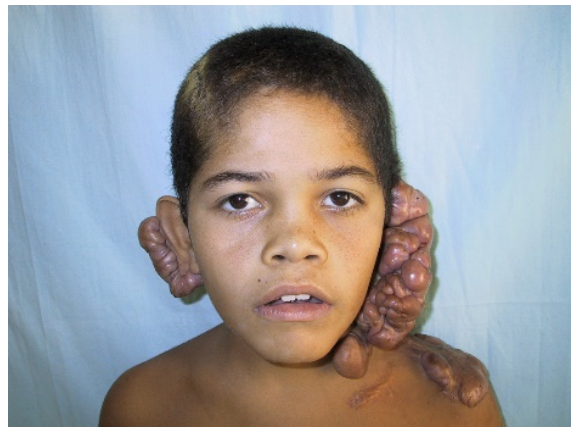

Figure 1. Preoperative period, face, 8 years old.

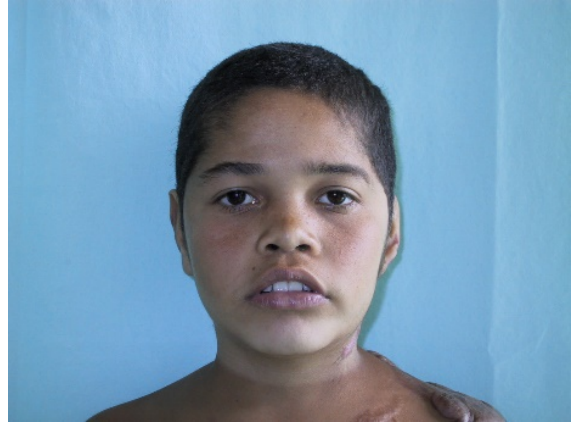

Figure 2. Final postoperative period, face, 8 years old. 


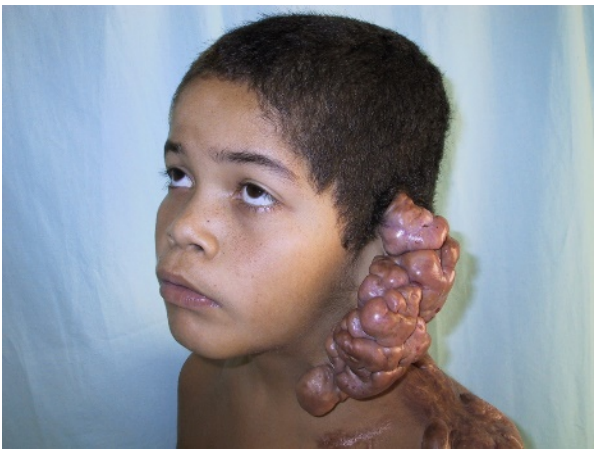

Figure 3. Preoperative, left side, 8 years old.

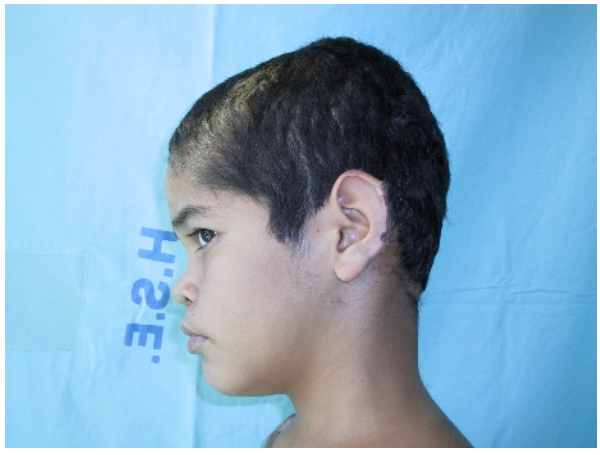

Figure 4. Postoperative, left side, 8 years old.



Figure 5. Perioperative-surgical specimen.

$2^{\text {nd }}$ extirpation:

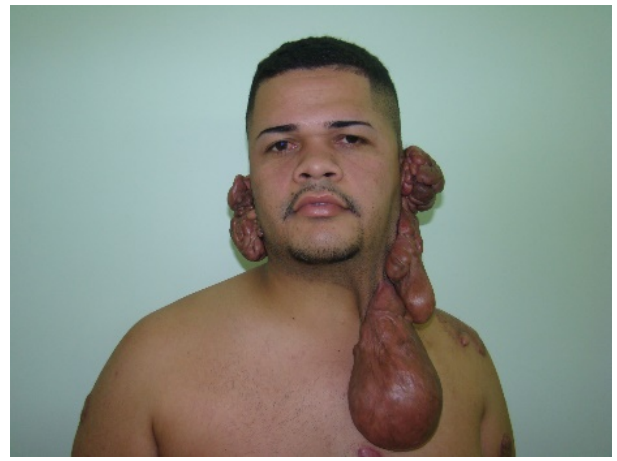

Figure 6. Preoperative face, recurrent, 22 years old. 


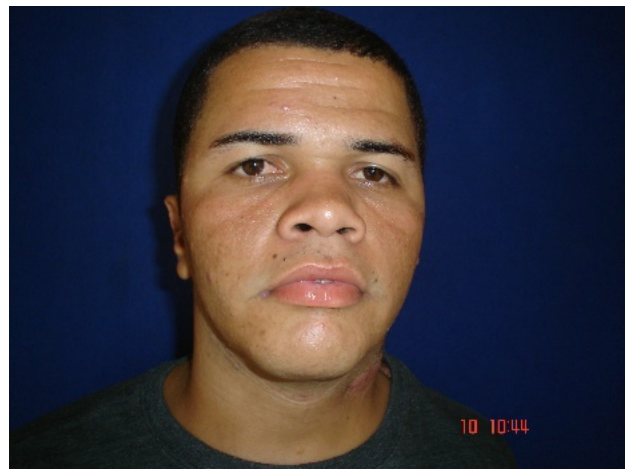

Figure 7. Post-operative, face, 22 years old and with after 6 months of surgery.

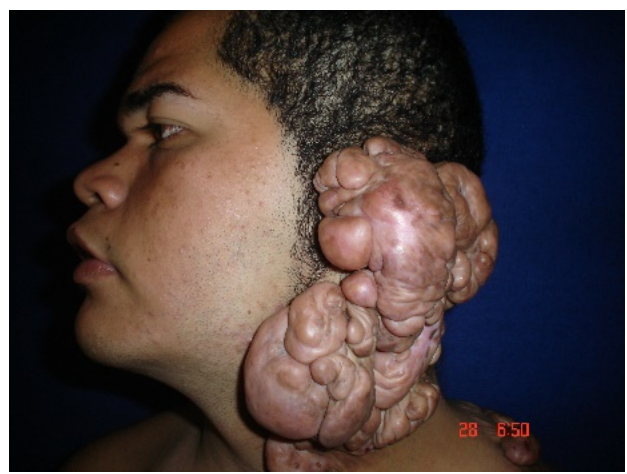

Figure 8. Preoperative left side, recurrent, 22 years old.

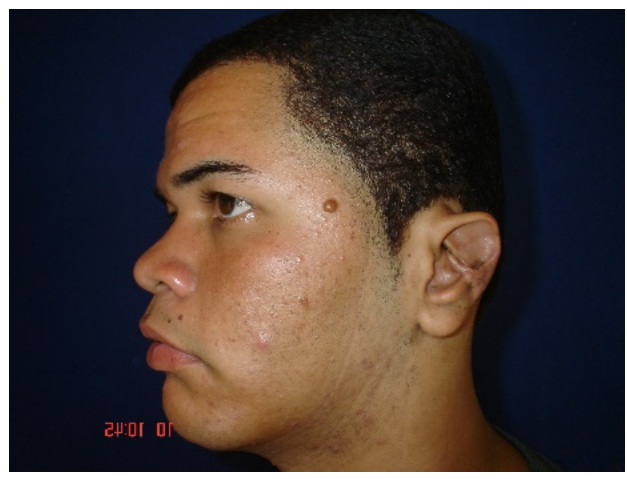

Figure 9. Postoperative, left side, 22 years old and after 6 months of surgery.

\section{Discussion}

The history of this patient with the disease of Jorge Lobo motivated the team to research more about its causes. Fungal infection to differentiate from a common keloid of the idiopathic cause or by racial problems. What attracted the most attention, in particular, was the volume of tumors and lobular shape without sequence. We also noticed the presence of a pruritus (itch) complaint in the lesions, which is very common in keloids found in other types of scars. Due to their irregular shapes, the lesions did not guide us to a technique of extirpation, 
which contributed to define a sequence based on the anatomy of the ear, that is, with many curves. In the first surgeries, at 8 years old, we had no experience with keloids with these characteristics, but, 14 years later, we performed a more severe preoperative and redoubled the post-operative care.

We discussed the possibilities of pre-operative infiltration of triamcinolone or compressive. We opted for beta-therapy in seven sessions immediately after surgery, on the same day, as stipulated by the radiotherapy team. Even so, we prescribed the facial elastic mesh for 12 months, in two stages: 6 months using 24 hours and 6 months using only at night. We monitored the patient for 12 months until he moved to another state in Brazil. Many ideas were presented, but we opted for those we had at that time.

As surgeons, we have had few cases similar to this. There were no cases of keloid in the procedures for placement of earrings or ornaments.

\section{Conclusion}

During our medical career, this was the biggest keloid we found and we had no idea how we were going to give hope to the patient, nor how to return his anatomically more perfect appearance and with all his anatomical accidents. We thought that, after the first discharge, at 8 years old, we would be away from possible relapses, considering all the possible instructions and warnings that were passed to the child's family, about the possibility of relapses if they did not move away from the endemic area where they lived and about changing habits, such as stop walking barefoot in the contaminated mire, be more careful with hygiene and use elastic mesh. The second time, at the age of 22, we were not so surprised, as we already knew that it could happen again. The giant "earring" shape caused deep embarrassment to the patient, which was the biggest reason for having gone to the hospital with the shirt covering the entire head. Even taking all the precautions we knew about keloids, we knew there would be a recurrence, which would result in a third surgical intervention, which did not happen. For this reason, we think it is a good idea to encourage medical colleagues to always try a second time, even though we know that we may fail. Perhaps the number of prophylactic measures and the patient's move to another less unhealthy location are the causes of the success of this case. There is no conflict of interest due to the care taken by the team to request authorization for publication.

\section{Conflicts of Interest}

The authors declare no conflicts of interest regarding the publication of this paper.

\section{References}

[1] Isaac, C., De Ladeira, P.R.S., Pires do Rêgo, F.M., Aldunate, J.C.B., Tutihashi, R.M.C. and Ferreira, M.C. (2011) Changes in the Physiological Repair Process. Brazilian Journal of Burns.

http://rbqueimaduras.org.br/details/67/pt-BR/alteracoes-no-processo-de-reparo-fisi 
ologico/

[2] Ferreira, C.M. and D’Assumpção, E.A. (2006) Hypertrophic Scars and Keloids. Revista da Sociedade Brasileira de Cirurgia Plástica, 21, 40-48.

http://www.rbcp.org.br/details/123/cicatrizes-hipertroficas-e-queloides

[3] Michel, P., Cláudio, G.Z., Marilda, C.F. and Pedro, B.E. (2019) Immunohistochemical Expression of Cyclooxygenases in Hypertrophic Scars and Keloids. Plastic and Reconstructive Surgery-Global Open, 7, e2030. https://doi.org/10.1097/GOX.0000000000002030

[4] Sanchéz, J., Garcia, M., Gallego, A. and Quilez, P. (2015) Prevención de cicatrices hipertróficas y queloides.

https://www.enfermeriadeciudadreal.com/prevencion-de-cicatrices-hipertroficas-yqueloides-462.htm

[5] Yong, M., Afshar, K., Macneily, A. and Arneja, J.S. (2013) Management of Pediatric Penile Keloid. Canadian Urological Association Journal, 7, 618-620.

https://doi.org/10.5489/cuaj.408

[6] Furtado, A.N., Andrade, H.S., Pandini, E.T., Motta, J., Frasson, P.H.L. and Falqueto, A. (2013). Jorge Lobo Disease: Case Report and Literature Review. Journal of Tropical Pathology, 42. https://doi.org/10.5216/rpt.v42i4.27931

[7] Canary, P.C.V., Fillipo, R., Pinto, L.H.P. and Aidar, S. (1990) Role of Radiotherapy in the Treatment of Keloids: A Retrospective Analysis of 267 Cases. Revista Brasileira de Cirurgia Cardiovascular, 80, 291-295.

[8] Cosman, B., Crikelair, G.F., Ju, D.M.C., Gaulin, J.C. and Lattes, R. (1961) The Surgical Treatment of Keloids. Plastic and Reconstructive Surgery, 27, 335-358. https://doi.org/10.1097/00006534-196104000-00001

[9] Bitencourt, E.L., Brandão, R.G.D., Andrade, A.E.P.R., Pimentel, N.F., Braga, L.P.C., Geraldelli, T.V., Costa, S.B. and Reis Júnior, P.M. (2020) Giant Ear Keloid: A Case Report. Journal of Pathology of Tocantins, 7, 18-21.

[10] Alster, T.S. (2003) Hypertrophic Scars and Keloids: Etiology and Management. American Journal of Clinical Dermatology, 4, 235-243. https://doi.org/10.2165/00128071-200304040-00003

[11] Correspondence and Comunication (2010) Use of Colchicine to Prevent Recurrence of Ear Keloids. A New Approach. Journal of Plastic, Recontructive and Aesthetic Surgery, 63, e650-e652. https://doi.org/10.1016/j.bjps.2010.03.018

[12] Carvalho, B., Ballin, A.C., Becker, R.V., Ribeiro, T.B., Cavichiolo, J.B., Ballin, C.R. and Mocellin, M. (2012) Treatment of Retroauricular Keloids: Review of Cases Treated at the Otorhinolaryngology Service of HC/UFPR. International Archives of Otorhinolaryngology, 16, 195-200. https://doi.org/10.7162/S1809-97772012000200007

[13] Botwood, N., Lewanski, C. and Lowdell, C. (1999) The Risks of Treating Keloids with Radiotherapy. The British Journal of Radiology, 72, 1022-1024. https://doi.org/10.1259/bjr.72.864.10703484

[14] Alster, T. (2003) Laser Scar Revision: Comparison Study of 585-nm Pulsed Dye Laser with and without Intralesional Corticosteroids. Dermatologic Surgery, 29, 25-29. https://doi.org/10.1097/00042728-200301000-00006

[15] Camacho-Martínez, F.M., Serrano, F.C., Rey, E.L. and Wagner, A. (2013) Results of a Combination of Bleomycin and Triamcinolone Acetonide in the Treatment of Keloids and Hypertrophic Scars. Anais Brasileiros de Dermatologia, 88, 387-394. https://doi.org/10.1590/abd1806-4841.20131802 
[16] Ledon, J.A., Savas, J., Franca, K., Chacon, A. and Nouri, K. (2013) Intralesional Treatment for Keloids and Hypertrophic Scars: A Review. Dermatologic Surgery, 39, 1745-1757. 